\title{
Microgram per Inhalation
}

National Cancer Institute

\section{Source}

National Cancer Institute. Microgram per Inhalation. NCI Thesaurus. Code C85703.

Micrograms per inhalation. 